\title{
PREFACE TO THE
}

\section{ENGLISH-LANGUAGE EDITION}

In French, the name of this book is la Jouissance. In English, Coming. In this way Charlotte Mandell solved the ever-renewed and strictly speaking impossible-tosolve difficulty posed by the translation of jouissance. This word designates the entire, limitless usage of a possession, with the twofold connotation of appropriation (or consommation, consumption) and pleasure carried to its height. (It stems from the Latin gaudium, joy, delight.) Hence its usage is divided into two distinct values: the legal meaning of complete ownership of a possession (one enjoys, jouit de, great wealth) or else the sensual meaning of a delectation or of voluptuousnessexclusively sexual voluptuousness following the usage that is dominant today in European French. The noun jouissance is thus used less to designate a state than the action or movement of jouir, enjoying - a verb that has also become mostly specialized in a sexual sense. 
It is this duality, this ambivalence, even this duplicity, that also takes into account-in the most recent usagesthe opposition between a consuming (or "consumerist," as we say in English) jouissance, turned toward accumulation or absorption, and a jouissance that is on the contrary ecstatic, carried away, dis-appropriating. The first value is put into play in social theory; the second remains limited in discourse to sex and/or the mystical. But the mystical seems today to have been relegated to history and the word jouissance has acquired an almost exclusively sexual intensity.

In English, sexual orgasm is expressed by the verb "to come." This has no corresponding noun. What is shared by both lexical registers is an idea of accomplishment. In French, we say venir (to come) for "reaching jouissance," but the word is mostly used between sexual partners ("viens!" for example). In choosing the gerund "coming," Charlotte Mandell aptly brings out action or movement, something that is in the process of occurring, which, in fact, is attached to jouissance and to jouir: that is, precisely what remains irreducible either to a state or to an acquisition, to an accomplishment or to an appropriation.

It is to this irreducibility that we have devoted the dialogue that follows.

Jean-Luc Nancy

viii Preface to the English-Language Edition 